\title{
KETERAMPILAN BERBICARA SISWA SEKOLAH DASAR MENGGUNAKAN VISUALISASI POSTER SEDERHANA
}

\section{Fatimah Nurul Aufa, Imaniar Purbasari, dan Eko Widianto}

Universitas Muria Kudus

Email: aufaaufaa282@gmail.com

\section{Info Artikel}

Sejarah Artikel:

Diserahkan 23 Juli 2020

Direvisi 10 Agustus 2020

Direvisi 9 November 2020

Disetujui 12 November 2020

Keywords:

speaking skills,

poster media,

elementary schools

\section{Abstract}

This study aims to describe the improvement of students' speaking skills through simple poster media on the theme of my hero grade IV SDN 1 Loram Kulon Kudus.

This research was conducted in class IV SDN 1 Loram Kulon with research subjects of 21 students. This research lasted for 2 cycles. Cycle 1, namely in sub-schemes 2 learning 1 and 3. Cycle 2 takes place in sub-schemes 2 in learning 4 and 6. Each cycle consists of 4 stages, namely planning, implementation, observation, and reflection.

This research shows that the use of poster media can improve speaking skills at SDN 1 Loram Kulon Kudus, this can be seen from the increase in cycle 1 to cycle 2 from $58 \%$ to $78 \%$ of the total 21 students.

\section{Abstrak}

Penelitian ini bertujuan mendeskripsikan peningkatan keterampilan berbicara siswa melalui media poster sederhana pada tema pahlawanku kelas IV SDN 1 Loram Kulon Kudus. Penelitian ini dilaksanakan pada kelas IV SDN 1 Loram Kulon dengan subjek penelitian 21 siswa. Penelitian ini berlangsung selama 2 siklus. Siklus 1 yaitu pada subtema 2 pembelajaran 1 dan 3. Siklus 2 berlangsung pada subtema 2 pembelajaran 4 dan 6. Setiap siklus terdiri dari 4 tahap yaitu perencanaan, pelaksanaan, pengamatan, dan refleksi.

Hasil penelitian menunjukkan bahwa penggunaan media poster dapat meningkatkan keterampilan berbicara SDN 1 Loram Kulon Kudus, hal ini dapat dilihat dari peningkatan siklus 1 ke siklus 2 dari $58 \%$ menjadi $78 \%$ dari total 21 siswa. 


\section{PENDAHULUAN}

Aspek keterampilan bahasa yang perlu dikuasai dan dipahami oleh seseorang siswa setelah mendengarkan yakni keterampilan berbicara. Keterampilan berbicara sangat penting dalam kehidupan sehari-hari karena manusia merupakan makhluk sosial yang berbicara dengan orang lain setiap hari. Kemampuan mengucapkan bunyi atau mengartikulasikan kata untuk mengungkapkan, mengungkapkan pikiran, ide dan perasaan disebut berbicara. Hal ini sejalan dengan pernyataan Agung (2008) yang mengartikan bahwa berbicara merupakan kegiatan kehidupan manusia normal yang sangat penting karena dengan berbicara kita dapat berkomunikasi dengan manusia, mengemukakan pendapat, menyampaikan gagasan dan pesan, mengekspresikan perasaan dalam semua kondisi emosional, dll. Dengan kata lain, berbicara dapat menjadi sarana komunikasi untuk menyatakan diri sebagai anggota masyarakat. Senada dengan itu, Nurjamal, Sumirat, dan Darwis (2011) berpendapat bahwa berbicara adalah kemampuan seseorang untuk menyampaikan gagasan, pendapat, dan sudut pandang secara verbal langsung kepada orang lain, baik secara langsung maupun tidak langsung. misalnya melalui radio, televisi.

Keterampilan berbicara perlu dikuasai oleh siswa sekolah dasar karena keterampilan ini terkait langsung dengan seluruh proses pembelajaran. Keberhasilan belajar siswa di sekolah sangat ditentukan oleh penguasaan keterampilan lisannya. Siswa yang belum mampu berbicara dengan benar dan baik akan kesulitan mengikuti kegiatan pembelajaran untuk semua mata pelajaran (Kurniasih, 2012). Artinya pembelajaran keterampilan berbicara menjadi penting karena melalui keterampilan tersebut siswa akan dapat mengembangkan kemampuan berpikir, membaca, menulis dan mendengarkan. Keterampilan berbicara sebagai keterampilan bahasa diajarkan di sekolah dasar, khususnya kelas IV mempunyai tujuan sebagai berikut, yaitu: (1) melatih anak melahirkan pikiran dan perasaan dengan sopan dan segera; (2) memperkaya kosa kata; (3) menumbuhkan atau mengembangkan perasaan keindahan konten dalam bahasa; dan (4) mengembangkan keterampilan peran (Kartohadikusumo, 1968: 117-118).

Observasi yang dilaksanakan oleh peneliti menemukan bahwa pada saat pembelajaran dikelas guru masih menggunakan bahasa jawa dari awal pembelajaran hingga berakhirnya pembelajaran, selain itu banyak siswa kurang percaya diri ketika menyampaikan pendapat, gagasan dan ide mereka. Penguasaan kosakata siswa kurang sehingga kesulitan dalam merangkai kata juga menjadi kendala siswa dalam berpendapat, ekspresi dan intonasi siswa dalam menyampaikan pendapat yang kurang juga menjadi permasalahan tersendiri.

Untuk mengatasi permasalahan tersebut perlu adanya media pembelajaran. Banyak batasan atau pengertian yang dikemukakan para ahli tentang media. Menurut Briggs (dalam Sadiman 2008) media adalah semua alat fisik yang dapat menyampaikan pesan dan merangsang siswa untuk belajar. Anderson (dalam Sukiman 2012) Media pembelajaran merupakan media yang memungkinkan terwujudnya hubungan langsung antara pekerjaan pengembang mata pelajaran dengan siswa.

Dari beberapa pendapat para ahli di atas dapat disimpulkan bahwa media pembelajaran adalah segala sesuatu yang dapat digunakan sebagai perantara atau saluran untuk menyampaikan pesan-pesan untuk merangsang pemikiran, perasaan dan perhatian siswa. selama proses pembelajaran. Media pembelajaran yang digunakan sangat mempengaruhi dan menunjang pemberian materi kepada siswa. Materi pembelajaran dapat berfungsi sebagai stimulus dan motivasi bagi siswa untuk berpartisipasi dalam pembelajaran.

Kreativitas siswa juga dapat dikembangkan jika penggunaan media yang tepat dan mampu menciptakan suasana yang menyenangkan, mendorong siswa untuk lebih aktif dan kreatif. Media tersebut juga digunakan untuk membantu guru memberikan bahan ajar. Tafonao (2018) mengemukakan bahwa keberadaan media atau alat peraga memudahkan pelaksanaan pembelajaran oleh guru. Selain itu, Siroj (2012) berpendapat bahwa membantu menghidupkan suasana kelas merupakan salah satu manfaat media pembelajaran agar siswa tidak bosan. Media yang digunakan dalam penelitian ini adalah media poster sederhana berupa gambar pahlawan materi tema pahlawanku subtema pahlawanku kebanggaanku, pada siklus I poster berupa gambar tokoh pahlawan Sultan Agung dan Sultan Hasanuddin dan pada siklus II poster berupa gambar tokoh pahlawan Pattimura dan Ir. Soekarno, media poster secara umum merupakan pesan yang ditulis baik berupa gambar yang bertujuan untuk menarik perhatian banyak orang. agar pesan yang disampaikan dapat dengan mudah diterima oleh orang lain. 
Riset mengenai keterampilan berbicara telah dilakukan oleh Rokhyani dan Cahyo (2015) dan Ayuandia, Saparahayuningsih, dan Ardina (2017). Riset Rokhyani dan Cahyo (2015) menyimpulkan bahwa bahwa teknik English Debate dapat digunakan bagi guru/dosen Bahasa Inggris untuk meningkatkan meningkatkan kemampuan/speaking mahasiswa. Di dalam teknik Englsh Debate ada topik yang mengharuskan bagi peserta debat untuk berbicara bahasa Inggris. Disamping itu, teknik English Debate juga dapat digunakan untuk meningkatkan kosakata mahasiswa. Sementara itu penelitian Ayuandia, Saparahayuningsih, dan Ardina (2017) membuktikan bahwa keterampilan berbicara anak dapat ditingkatkan melalui metode karyawisata, dengan ketuntasan belajar $84,2 \%$ rata-rata keterampilan berbicara anak 4,21 (Baik).

Berdasarkan uraian diatas maka penelitian ini bertujuan untuk mengetahui peningkatan keterampilan berbicara siswa dengan menggunakan poster sederhana bertema Pahlawan di SDN 1 Loram Kulon Kudus.

\section{METODE PENELITIAN}

Jenis penelitian ini adalah penelitian tindakan kelas (PTK) atau Classroom Action Research (CAR). Penelitian dilaksanakan di kelas IV SDN 1 Loram Kulon Kudus, yang terletak di Kecamatan Jati Kabupaten Kudus. Penelitian dilaksanakan pada semester I tahun 2019/2020. Desain penelitian tindakan kelas yang digunakan peneliti dalam penelitian ini adalah model Kemiss dan Mc Taggart, yang dapat dilihat pada Gambar 1 berikut.

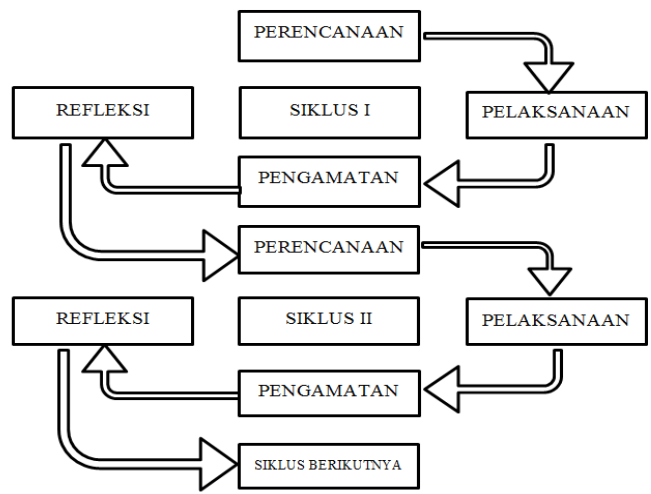

Gambar 1. Desain Penelitian Tindakan Kelas

Penelitian dilaksanakan sesuai dengan alur desain, penelitian tindakan kelas dengan acuan Gambar 1 di atas. Siklus 1 dimulai dari perencanaan yaitu mempersiapkan semua yang dibutuhkan dalam penelitian, kemudian peneliti melakukan penelitian sesuai waktu dan tempat yang telah disusun, kemudian dilakukan observasi selama penelitian, langkah selanjutnya adalah refleksi. Pelaksanaan penelitian pada siklus II seperti siklus I. Jika tidak ada masalah pada tahap refleksi siklus II maka tidak perlu melanjutkan ke Siklus III.

Sumber data yang digunakan untuk mengetahui keterampilan lisan siswa yaitu Kelas IV SDN 1 Loram Kulon Kudus dan guru. Metode pengumpulan data dan instrumen yang digunakan dalam penelitian ini adalah sebagai berikut (1) Observasi, peneliti mengamati pelaksanaan pembelajaran di kelas dan masalahmasalah yang muncul selama pembelajaran. (2) Wawancara, peneliti mewawancarai siswa untuk menemukan masalah secara lebih terbuka. (3) Dokumentasi, untuk kepentingan peneliti dan penelitian lebih tepatnya diperlukan foto dan dokumen sebagai bukti. Dokumentasi dari penelitian ini digunakan untuk menyelesaikan tugas akhir peneliti.

Analisis data dalam penelitian ini menggunakan teknik analisis data kuantitatif dan kualitatif untuk memastikan kemampuan ekspresi diri siswa pada topik Pahlawan Kelas IV SD N 1 Loram Kulon berbantuan oleh media poster sederhana. Analisis data dapat diperoleh baik dari data kuantitatif maupun data kualitatif yang dianalisis secara deskriptif.

Data kuantitatif dalam penelitian diperoleh dari instrumen tes berupa skor hasil evaluasi siswa yang kemudian dianalisis menggunakan teknik analisi statistik deskriptif dengan menentukan presentase ketuntasan belajar peserta didik pada akhir siklus. Penelitian ini memberikan penilaian terhadap keterampilan berbicara siswa pada aspek keterampilan masingmasing siswa. Indikator keterampilan berbicara dapat dilihat pada Tabel 1.

Tabel 1 Indikator Keterampilan Berbicara

\begin{tabular}{cc}
\hline No & Indikator keterampilan berbicara \\
\hline 1 & Kelancaran berbicara \\
2 & Ketepatan pilihan kata \\
3 & Struktur kalimat \\
4 & Intonasi membaca kalimat \\
5 & Ekspresi \\
\hline
\end{tabular}

(Permana 2015)

Berdasarkan tabel kriteria kecakapan lisan di atas, peneliti memodifikasinya dengan menghilangkan salah satu kriteria keterampilan berbicara berupa kelancaran. Indikator penguasaan kemampuan berbicara dalam 
penelitian ini tidak digunakan karena yang ingin ditunjukkan oleh peneliti adalah keberanian dan keterampilan siswa dalam mengungkapkan pendapatnya di depan teman-temannya. Penguasaan istilah lebih pada bercerita atau bercerita. Berikut ini adalah aspek penilaian keterampilan berbicara.

Tabel 2. Kriteria Keterampilan Berbicara

\begin{tabular}{cll}
\hline No & \multicolumn{1}{c}{ Kriteria } & \multicolumn{1}{c}{ Aspek Penilaian } \\
\hline 1 & $\begin{array}{l}\text { Kesesuaian ucapan } \\
\text { dengan topik }\end{array}$ & $\begin{array}{l}\text { Berbicara sesuai } \\
\text { dengan gambar dan } \\
\text { materi yang } \\
\text { didiskusikan }\end{array}$ \\
2 & $\begin{array}{l}\text { Ketepatan pemilihan } \\
\text { kata dan ejaan }\end{array}$ & $\begin{array}{l}\text { Menggunakan kata } \\
\text { yang tepat sesuai EYD }\end{array}$ \\
3 & $\begin{array}{l}\text { Ketepatan } \\
\text { penyusunan kalimat }\end{array}$ & $\begin{array}{l}\text { Menggunakan kalimat } \\
\text { yang tepat }\end{array}$ \\
4 & Intonasi dan ekspresi & $\begin{array}{l}\text { Menggunakan nada, } \\
\text { tempo, dan ekspresi } \\
\text { yang sesuai }\end{array}$ \\
\hline
\end{tabular}

(Modifikasi Peneliti)

\section{HASIL DAN PEMBAHASAN}

Hasil dari penelitian tindakan kelas yang dilaksanakan pada tanggal 9-12 Desember 2019 menunjukkan bahwa media poster sederhana dapat meningkatkan keterampilan berbicara siswa kelas IV SDN 1 Loram Kulon Kudus. Penelitian ini dilakukan pada cakupan materi tema 5 Pahlawanku subtema 2 Pahlawanku Kebangaanku muatan Pkn dan Bahasa Indonesia.

Tabel 3. Perhitungan Hasil Keterampilan Berbicara Aspek Psikomotorik Siklus 1

\begin{tabular}{cc}
\hline Komponen & Hasil \\
\hline Total skor & 183 \\
Rata-rata & 8,7 \\
Persentase & $58 \%$ \\
Kriteria & Cukup \\
\hline
\end{tabular}

Berdasarkan Tabel 3 dapat diketahui bahwa keterampilan berbicara pada siklus 1 dalam kriteria cukup, dengan persentase $58 \%$.

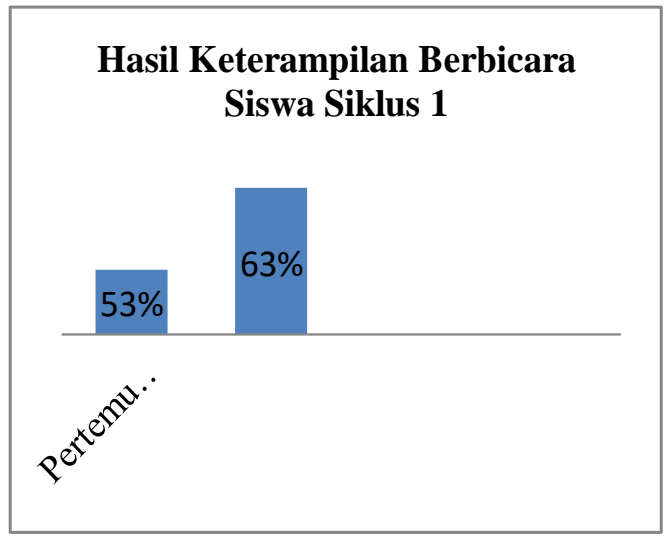

Gambar 2. Diagram Peningkatan Keterampilan Berbicara Siswa Kelas IV SD N 1 Loram Kulon Kudus Siklus 1 (Sumber: data primer)

Berdasarkan Gambar 1 diketahui bahwa nilai keterampilan berbicara siswa siklus 1 pertemuan 1 sebesar $53 \%$ dan siklus 1 pertemuan 2 sebesar $63 \%$. Hal ini dapat disimpulkan bahwa nilai keterampilan berbicara siswa meningkat $10 \%$. Akan tetapi nilai keterampilan berbicara siswa secara klasikal siklus 1 masih belum mencapai indikator keberhasilan.

Siklus II sudah ada peningkatan, pada siklus II siswa sudah percaya diri dalam mengungkapkan pendapatnya di depan kelas. Percaya diri sangat berpengaruh dengan kualitas keterampilan berbicara, kepercayaan diri atau keyakinan diri diartikan sebagai suatu kepercayaan terhadap diri sendiri yang dimiliki setiap individu dalam kehidupannya, serta bagaimana individu tersebut memandang dirinya secara utuh dengan mengacu pada konsep diri (Rakhmat, 2000). Lauster (Fasikhah, 1994), menyatakan bahwa kepercayaan diri merupakan suatu sikap atau perasaan yakin atas kemampuan diri sendiri sehingga orang yang bersangkutan tidak terlalu cemas dalam tindakan-tindakannya, dapat merasa bebas untuk melakukan hal-hal yang disukainya dan bertanggung jawab atas perbuatannya, hangat dan sopan dalam berinteraksi dengan orang lain, dapat menerima dan menghargai orang lain, memiliki dorongan untuk berprestasi serta dapat mengenal kelebihan dan kekurangannya. 
Fatimah Nurul Aufa, Imaniar Purbasari, dan Eko Widianto

KETERAMPILAN BERBICARA SISWA SEKOLAH DASAR MENGGUNAKAN VISUALISASI POSTER .... WASIS : Jurnal Ilmiah Pendidikan. Volume 1, Nomor 2, November 2020, hlm. 86-92

Tabel 4. Perhitungan Hasil Keterampilan Berbicara Aspek Psikomotorik Siklus 2

\begin{tabular}{cc}
\hline Komponen & Hasil \\
\hline Total skor & 506 \\
Rata-rata & 12 \\
Persentase & $75 \%$ \\
Kriteria & Baik \\
\hline
\end{tabular}

Berdasarkan Tabel 4 dapat diketahui bahwa keterampilan berbicara pada siklus 2 dalam kriteria Baik, dengan persentase $75 \%$.

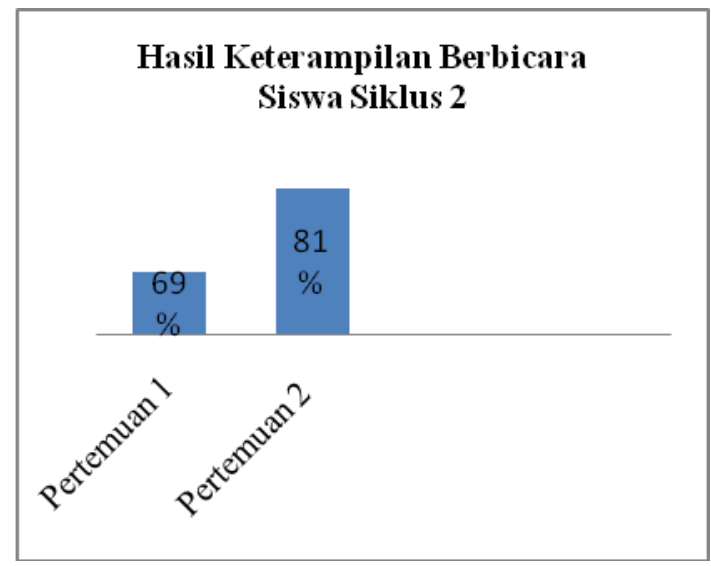

Gambar 3 Diagram Peningkatan Keterampilan Berbicara Siswa Kelas IV SD N 1 Loram Kulon Kudus Siklus 2

(sumber: data primer peneliti)

Berdasarkan Gambar 3 diketahui bahwa nilai keterampilan berbicara siswa siklus 2 pertemuan 1 sebesar $69 \%$ dan siklus 2 pertemuan 2 sebesar $81 \%$. Hal ini dapat disimpulkan bahwa nilai keterampilan berbicara siswa meningkat $12 \%$. Hasil keterampilan berbicara siswa siklus 2 sudah mencapai kriteria baik.

\section{Keterampilan Berbicara Siswa}

Keterampilan berbicara siswa kelas IV SDN 1 Loram Kulon Kudus dikatakan rendah. Hal tersebut terjadi karena proses pembelajaran masih menerapkan model konvensional dan proses pembelajaran kurang optimal, siswa kurang diberikan kesempatan utuk mengambangkan keterampilan berbicaranya oleh guru, dan apabila ada materi yang kurang di pahami siswa, siswa pun belum ada keberanian untuk bertanya kepada guru.

Hasil penelitian keterampilan berbicara siswa pada Tema 5 Pahlawanku berbantuan media poster mengalami peningkatan setiap siklusnya. Pada siklus I hasil nilai rata-rata yang diperoleh yakni 8,7 dengan kategori cukup predikat $\mathrm{C}$, sedangkan pada siklus II jumlah nilai rata-rata klasikal keterampilan berbicara siswa meningkat menjadi 12 dengan kategori baik predikat B. Berikut tabel 5 hasil peningkatan keterampilan berbicara siswa kelas IV SDN 1 Loram Kulon Kudus.

Tabel 5. Peningkatan keterampilan berbicara siswa kelas IV SDN 1 Loram Kulon Kudus.

\begin{tabular}{ccc}
\hline Komponen & Siklus I & Siklus II \\
\hline Total nilai & 8,7 & 12 \\
Kriteria & Cukup & Baik \\
Predikat & C & B \\
Kesimpulan & & Meningkat \\
\hline
\end{tabular}

Berdasarkan hasil siklus I dan siklus II menunjukkan bahwa terjadi peningkatan keterampilan berbicara siswa dari kriteria cukup menjadi kriteria baik. Peningkatan keterampilan berbicara siswa disajikan dalam Gambar 4.

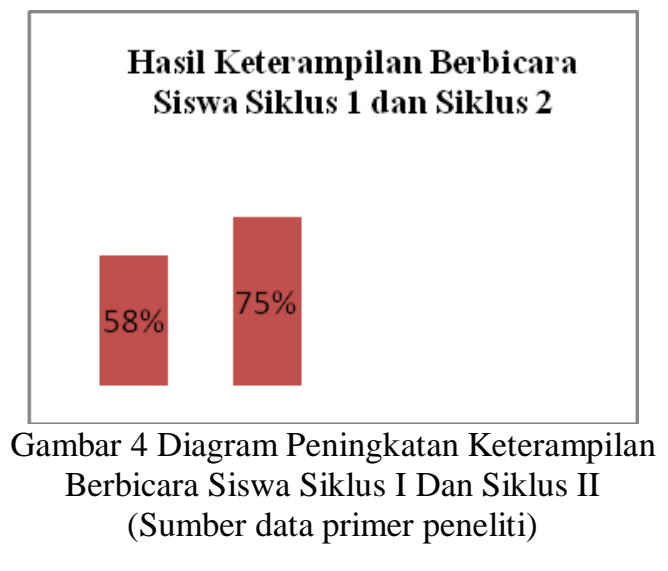

Berdasarkan hasil penelitian, keterampilan berbicara siswa yang dicapai dengan media poster sederhana meningkat. Hal ini dapat dilihat dari pencapaian indikator keterampilan berbicara, termasuk hasil kesesuaian bicara dengan topik, ketepatan pilihan kata dan ejaan, ketepatan pengaturan kalimat, intonasi dan ekspresi. Indikator (1) kecukupan tuturan dengan subjek. Pada indikator ini menjelaskan bagaimana siswa menanggapi pertanyaan yang diajukan oleh guru dan siswa lain yang mengajukan pertanyaan. Pada siklus I, banyak siswa tidak berani mengungkapkan pendapat mereka, banyak siswa tidak berbicara sesuai dengan materi yang dibahas. Hal ini dikarenakan siswa masih kurang dalam memahami materi yang diajarkan oleh guru. Guru juga tidak menjelaskan materi secara luas dan merata. Siswa di belakang tidak mendengar penjelasan guru. Setelah guru menjelaskan materi lebih luas dan lebih fokus pada siswa dengan berbantuan poster sederhana pada siklus 
dua, banyak siswa yang dapat menjawab pertanyaan guru jika guru mengajukan pertanyaan secara lisan.

Indikator (2) ketepatan pemilihan kata dan ejaan. Indikator ini menjelaskan bagaimana siswa menggunakan tata bahasa saat mengajukan pertanyaan, mengkomunikasikan hasil diskusi dan mengungkapkan pendapat. Pada siklus I hanya sedikit siswa yang berani mengutarakan pendapatnya, dan untuk mengutarakan pendapatnya, siswa tersebut bahkan lebih sedikit menggunakan tata bahasa karena siswa masih mencampurkan bahasa daerah yang sering digunakan untuk berbicara, dan penggunaan bahasa Indonesia tidak mengikuti. bukan aturan yang berlaku. Dengan bimbingan guru, siswa siklus II mulai bisa menggunakan tata bahasa yang mengikuti aturan yang berlaku pada EYD.

Indikator (3) ketepatan penyusunan kalimat. Pada indikator ini menjelaskan bagaimana siswa mengungkapkan pendapatnya, ketika siswa menyampaikan jawaban atau jenisnya saat berdebat dengan siswa lain yang maju untuk menyampaikan hasil diskusinya. Pada Siklus I, hanya sedikit siswa yang berani membantah tanggapan temannya ketika muncul di depan kelas karena tidak percaya diri dan malu ketika ada kesalahan. siswa mulai berani mengungkapkan pendapatnya ketika siswa lain melangkah maju untuk menyampaikan hasil diskusinya. Hal tersebut dipertegas oleh pendapat Tarigan (2015: 3) yang menyatakan bahwa berbicara adalah suatu keterampilan menyatakan, menyampaikan, mengkomunikasikan gagasan yang disusun dan dikembangkan sesuai dengan kebutuhan pendengar atau pendengarnya.

Indikator (4) intonasi dan ekspresi. Pada indikator ini menjelaskan bagaimana siswa berbicara, menjelaskan hasil diskusi yang telah dilaksanakan, menjelaskan materi atau pendapat yang disampaikan. Pada Siklus Satu, siswa mengungkapkan pendapatnya dengan tempo, nada, ekspresi, dan gerak tubuh yang tidak tepat karena siswa kurang percaya diri dan rasa takut. Setelah menerapkan model pembelajaran open problem dengan bantuan poster dan bimbingan guru, siswa siklus II mampu berbicara dengan jelas, berbicara dengan tempo, nada, ekspresi, dan gerak tubuh yang tepat saat mempresentasikan hasil diskusi, mengemukakan pendapat dan mengajukan pertanyaan.

Hasil penelitian yang dilakukan senada dengen riset Setiawan (2016) dan Darmuki dan Hariyadi (2019). Setiawan (2016) menyimpulkan bahwa Pembelajaran PKn menggunakan pendekatan belajar melalui karya poster untuk mengenalkan materi globalisasi dapat meningkatkan hasil belajar pada aspek kognitif, afektif dan psikomotorik. Peningkatan pada aspek kognitif dilihat pada siklus I ke siklus II yaitu nilai rata-rata 69,55 naik menjadi 77,05 , Pada aspek afektif dilihat dari siklus I ke siklus II yaitu dari $62,5 \%$ kriteria cukup naik menjadi $84,43 \%$, dengan kriteria baik, Sedangkan Pada aspek psikomotorik dilihat siklus I ke siklus II yaitu dari 56,02\% kriteria cukup naik menjadi $84,21 \%$ berada pada kriteria baik. Sementara itu penelitian Darmuki dan Hariyadi (2019) membuktikan bahwa menunjukkan adanya peningkatan hasil pembelajaran berbicara, ditandai dengan meningkatnya jumlah mahasiswa yang mencapai batas ketuntasan, yaitu pada siklus I ada 32 mahasiswa (80\%), pada siklus II ada 38 mahasiswa (95\%), dan pada siklus III ada 40 mahasiswa (100\%).

\section{SIMPULAN}

Peningkatan keterampilan berbicara pada siswa kelas 4 SDN 1 Loram Kulon Kudus meningkat karena di adakannya media poster sederhana. Dapat disimpulkan bahwa pada pelaksanaan siklus I ke siklus II mengalami peningkatan, peningkatan keterampilan berbicara tersebut adalah $58 \%$ dari siklus I menjadi $75 \%$ pada siklus II dari jumlah total 21 siswa.

Berdasarkan penelitian yang telah dilaksanakan dengan menggunakan media poster sederhana ternyata dapat meningkatkan keterampilan berbicara siswa kelas 4 SDN 1 Loram Kulon Kudus. Adanya peningkatan keterampilan berbicara siswa terbukti atas pencapaian pada setiap indikator-indikator keterampilan berbicara,diantaranya indikator hasil kesesuaian ucapan dengan topik, ketepatan pemilihan kata dan ejaan, ketepatan penyusunan kalimat, intonasi dan ekspresi

\section{DAFTAR PUSTAKA}

Agung, A. 2008. Keterampilan Berbicara Rhetorika Dan Berbicara Efektif. Diperoleh 29 September 2011 http:student.eepisits.edu/yakfiy/berbicara \%. Jurnal Penelitian Bahasa, Sastra Indonesia dan Pengajarannya 1.

Ayuandia, Nera., Saparahayuningsih, Sri., dan Ardina, Mona. 2017. Meningkatkan Keterampilan Berbicara Melalui Metode Karyawisata Pada Anak Kelompok B Lab School PAUD UNIB Kota Bengkulu. Jurnal Potensia, 2 (1): 32-38. 
Darmuki, Agus dan Hariyadi, Ahmad. 2019. Peningkatan Keterampilan Berbicara Menggunakan Metode Kooperatif Tipe Jigsaw Pada Mahasiswa PBSI Tingkat I-B IKIP PGRI Bojonegoro Tahun Akademik 2018/2019. Kredo : Jurnal Ilmiah Bahasa dan Sastra, 2 (2): 256-267.

Fasikhah, S.S. 1994. Peranan Kompetensi Sosial Pada T.L Koping Remaja Akhir. Tesis. Yogyakarta: Universitas Gadjah Mada.

Kartohadikusumo, S.M. 1968. Kurikulum Sekolah Dasar 1968. Jakarta: Direktorat Pendidikan Prasekolah/Sekolah Dasar/S.L.B Direktorat Jenderal Pendidikan Dasar Departemen Pendidikan dan Kebudayaan.

Nurjamal, D., Warta S, Riadi D. 2011. Terampil Berbahasa. Bandung: Alfabeta.

Permana, Erwin Putera. 2015. Pengembangan Media Pembelajaran Boneka Kaos Kaki Untuk Meningkatkan Keterampilan Berbicara Siswa Kelas II Sekolah Dasar. Skripsi. Kudus: Universitas Muria Kudus.

Rakhmat, J. 2000. Psikologi Agama. Jakarta: Raja Grafindo Persada.

Rokhayani, Atik dan Cahyo, Agung Dwi Nur. 2015. Peningkatan Ketrampilan Berbicara (Speaking) Mahasiswa Melalui Teknik English Debate. Refleksi Edukatika: Jurnal Ilmiah Kependidikan, 5 (1).
Sadiman, Arief dkk. 2010. Media Pendidikan: Pengertian Pengembangan dan Pemanfaatannya. Jakarta: Rajawali Pers.

Setiawan, Deka. 2016. Pendekatan Belajar Melalui Karya Poster Dalam Mengenalkan Materi Globalisasi Pada Mata Pelajaran Pkn Untuk Siswa Kelas IV SD Ngembalrejo Kabupaten Kudus, Refleksi Edukatika : Jurnal Ilmiah Kependidikan, 6 (2).

Sugiyono. 2015. Metode Penelitian Pendidikan. Bandung Alfabeta.

Sukiman. Pengembangan media pembelajaran. Jogjakarta: PT. Pustaka Insan Madani Anggara.

Tarigan, Henry Guntur. 2008. Berbicara Sebagai Suatu Keterampilan Berbahasa. Bandung: Angkasa. 